\section{INOVASI AKAR RUMPUT}

"Proses Pemunculan dan Peranan Kepemimpinan"

\section{(Belajan Dani Desa Wisata)}

Inovasi akar rumput muncul sebagai alternatif atas ketidakmampuan inovasi konvensional menyelesaikan masalah masyarakat di tingkat grassroot (akar rumput). Di Indonesia, komunitas akar rumput cenderung lebih tepat disematkan pada masyarakat pedesaan. Berbagai kebijakan dan inovasi telah dilakukan oleh pemerintah untuk menyelesaikan masalah desa, namun model topdown ternyata masih belum efektif. Desa akhimya berinovasi mandiri secara bottom-up dari dan oleh masyarakat desa itu sendiri. Contoh terbaik dapat dilihat dari apa yang dilakukan oleh Desa Pentingsari dengan berubah menjadi desa wisata sejak tahun 2008. Keberhasilan Desa Pentingsari bertransformasi menjadi desa wisata menjadi hal menarik untuk diteliti dan kemudian ditulis sebagaimana isi dari buku ini, khususnya terkait dengan proses pemunculan inovasi dan peranan kepemimpinan akar rumput dalam proses inovasi yang dilakukan.

Penelitian yang dilakukan menemukan beberapa hasil penting, bahwa proses novasi dimulai dengan dorongan dari tiga motivasi utama, dilanjutkan dengan kegiatan pengamatan sederhana, pembentukan jaringan internal dan eksternal, hingga tahap aktivitas/gerakan yang menandai dimulainya inovasi. Pemimpin akar rumput juga memegang peranan strategis dalam keberhasilan proses pemunculan inovasi yang dilakukan dengan memberikan motivasi, membentuk visi bersama, membentuk jaringan, dan membuat sistem kerja. Meskipun tanpa dukungan pendanaan dari pihak luar dan harus mengorbankan banyak material serta harta pribadi, pemimpin akar rumput sukses memimpin proses inovasi akar rumput di Desa Pentingsari hingga berhasil menjadi salah satu desa wisata terbaik dunia.

$\mathrm{Ya}$, itulah sejatinya inovasi akar rumput yang memang berbeda dengan inovasi konvensional (main stream) yang biasa kita dengar. Buku yang ditulis berdasarkan hasil penelitian tentang keberhasilan Desa Pentingsari di Yogyakarta menerapkan inovasi akar rumput ini diharapkan mampu memberikan pengetahuan kepada pembaca tentang apa itu inovasi akar rumput, bagaimana proses pemunculannya, apa saja faktor yang mempengaruhi proses tersebut dilakukan, dan bagaimana peranan kepemimpinan akar rumput dalam proses inovasitersebut. Selamatmembaca!
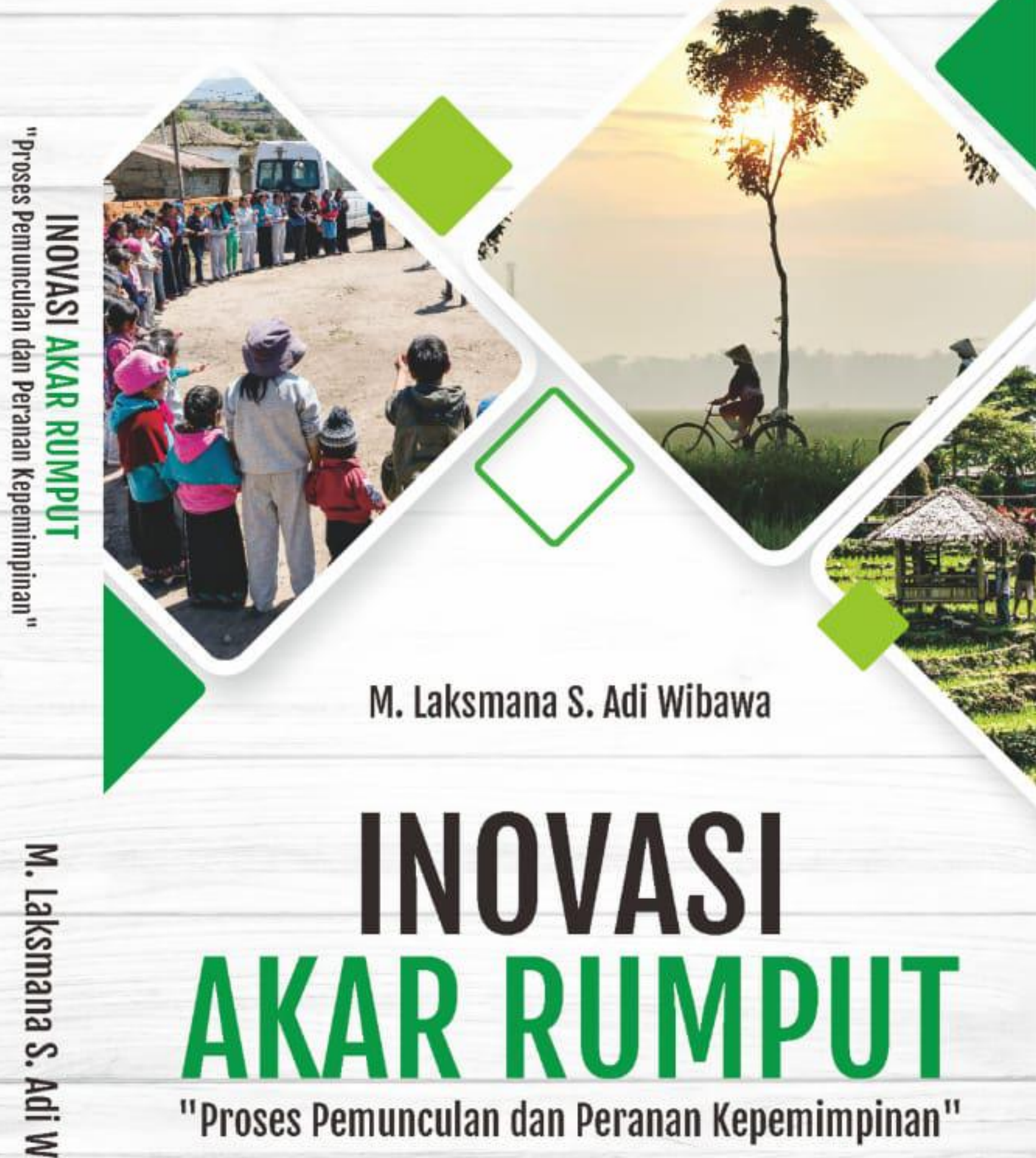

(Belajan Dani Desa Wisata)

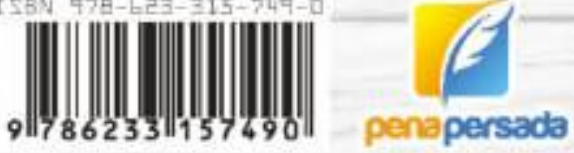




\title{
INOVASI AKAR RUMPUT "PROSES PEMUNCULAN DAN PERANAN KEPEMIMPINAN"
}

\author{
M. Laksmana S. Adi Wibawa
}




\section{INOVASI AKAR RUMPUT "PROSES PEMUNCULAN DAN PERANAN KEPEMIMPINAN "}

Penulis:

M. Laksmana S. Adi Wibawa

ISBN: 978-623-315-749-0

\section{Design Cover:}

Retnani Nur Briliant

Layout:

Nofendy Ardyanto

\section{Penerbit CV. Pena Persada \\ Redaksi:}

Jl. Gerilya No. 292 Purwokerto Selatan, Kab. Banyumas

Jawa Tengah

Email: penerbit.penapersada@gmail.com

Website: penapersada.com Phone: (0281) 7771388

\section{Anggota IKAPI}

All right reserved

Cetakan pertama: 2021

Hak Cipta dilindungi oleh undang-undang. Dilarang memperbanyak karya tulis ini dalam bentuk apapun tanpa izin penerbit 


\section{KATA PENGANTAR}

Segala puji senantiasa kita panjatkan Kehadirat Tuhan Yang Maha Esa, atas segala Rahmat dan Karunia-Nya, akhirnya penulis dapat menyelesaikan penyusunan buku yang berjudul "INOVASI AKAR RUMPUT "PROSES PEMUNCULAN DAN PERANAN KEPEMIMPINAN"". Saya menyadari bahwa tanpa bantuan dan bimbingan dari berbagai pihak sangatlah sulit bagi saya untuk menyelesaikan karya ini. Oleh karena itu, saya mengucapkan banyak terima kasih pada semua pihak yang telah membantu penyusunan buku ini. Sehingga buku ini bisa hadir di hadapan pembaca.

Buku ini membahas tentang inovasi akar rumput "Proses Pemunculan Dan Peranan Kepemimpinan". Inovasi merupakan upaya atau usaha untuk mengembangkan, memperbaiki dan memanfaatkan sesuatu yang sebelumnya menjadi lebih baik atau leboh optimal. Salah satu pendekatan yang digunakan pada pengembangan sebuah desa wisata di Desa Pentingsari adalah inovasi akar rumput, yaitu serangkaian kegiatan kelompok masyarakat dan aktivis yang bekerjasama dengan orang-orang untuk menghasilkan produk atau solusi dari bawah ke atas untuk pembangunan berkelanjutan. Tentu saja hal ini kan meningkatakan perekonomian yang luar biasa bagi masyarakat di Desa Wisata Pentingsari.

Penulis menyadari bahwa buku ini masih jauh dari kesempurnaan. Oleh karena itu kritik dan saran yang membangun sangat dibutuhkan guna penyempurnaan buku ini. Akhir kata saya berharap Tuhan Yang Maha Esa berkenan membalas segala kebaikan semua pihak yang telah membantu.

Penulis 


\section{DAFTAR ISI}

KATA PENGANTAR .............................................................. iii

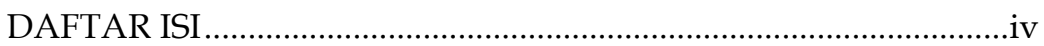

BAB 1 PENDAHULUAN................................................................ 1

A. Keberadaan Inovasi dalam Permasalahan Masyarakat.1

B. Inovasi Menggunaakan Pendekatan Akar Rumput.......2

C. Inovasi Pada Desa Wisata Pentingsari ........................... 4

D. Kepemimpinan Akar Rumput ...................................... 7

BAB II INOVASI AKAR RUMPUT …........................................... 9

A. Pengertian Inovasi ......................................................... 9

B. Inovasi Akar Rumput ................................................. 12

C. Proses Inovasi Akar Rumput.........................................15

D. Faktor Pendorong dan Penghambat Inovasi Akar Rumput................................................................... 19

BAB III KEPEMIMPINAN AKAR RUMPUT ................................26

A. Pengertian Kepemimpinan ........................................ 26

B. Kepemimpinan Akar Rumput ..................................... 28

C. Fenomena Elite Capture (Penguasaan Elit) ..................34

BAB IV GAMBARAN UMUM DESA WISATA PENTINGSARI.37

A. Kondisi Geografis Desa Pentingsari ............................. 37

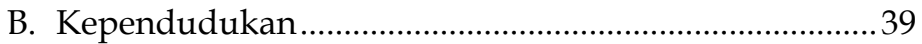

C. Potensi Wisata Desa........................................................ 40

D. Paket Wisata Desa ...........................................................49

BAB V PROSES PEMUNCULAN INOVASI AKAR RUMPUT.....55

A. Kesadaran/Motivasi....................................................55

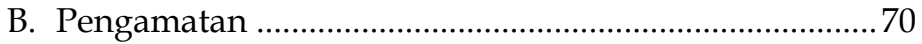

C. Pembentukan Jaringan ................................................. 76

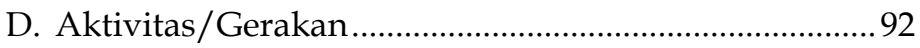

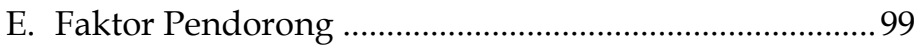

F. Faktor Penghambat................................................ 148

BAB VI PERANAN KEPEMIMPINAN AKAR RUMPUT

DALAM PROSES PEMUNCULAN INOVASI AKAR RUMPUT ........................................................................ 181

A. Motivasi/Kebutuhan .................................................. 182

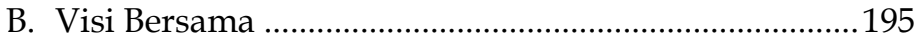




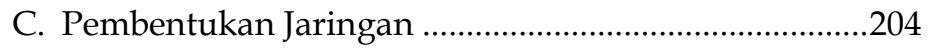

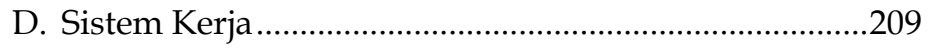

E. Dukungan Pendanaan ....................................................222

F. Fenomena Penguasaan Elit (Elite Capture) ....................228

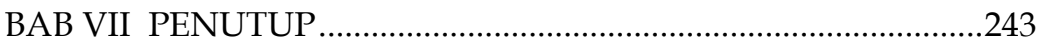

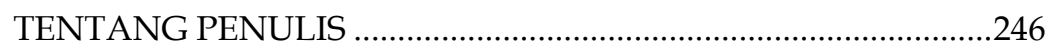

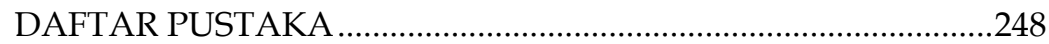




\section{INOVASI AKAR RUMPUT "PROSES PEMUNCULAN DAN PERANAN KEPEMIMPINAN"}




\section{BAB 1 \\ PENDAHULUAN}

\section{A. Keberadaan Inovasi dalam Permasalahan Masyarakat}

Inovasi sejatinya tak selalu soal anggaran Research and Development yang besar, aplikasi pintar pada ponsel, hak paten atau bahkan tentang ekspor produk berteknologi tinggi (hightech) saja, namun juga bergerak pada pada ide, kecerdikan dan terkadang 'hanya' melalui improvisasi (Bubel et al., 2015). Beberapa tokoh lainnya bahkan secara tegas menentang status quo dari praktik dan nilai-nilai inovasi umum yang berlaku. Boldrin \& Levine (2008) dan Agola \& Hunter (2016) sepakat bahwa hak paten tidak cocok untuk sebuah inovasi yang mungkin hanya akan menguntungkan sebagian besar orang saja dan mengesampingkan masyarakat yang terpinggirkan. Sedangkan Ross et al., (2012) menyebutkan bahwa inovasi tak harus berdasar pada research and development konvensional, serta tidak pula harus berbicara tentang teknologi canggih (Hossain, 2016; Hua et al., 2010).

Inovasi arus utama (konvensional) memerlukan pengembangan metode baru yang lebih sesuai dengan kondisi lokal (Ahmed \& Al-Roubaie, 2012). Proses inovasi perlu dibuka untuk pengawasan publik yang lebih besar, partisipasi yang lebih luas, dan etika yang lebih bertanggung jawab secara sosial (Smith \& Stirling, 2016). Inovasi akar rumput kemudian tumbuh sebagai alternatif atas kesenjangan konsep tersebut dan tidak relevannya inovasi konvensional dalam menyelesaikan masalah masyarakat lokal (Dana et al., 2019; Hossain, 2016; Smith, 2016). Pandangan beberapa tokoh tersebut memberikan gambaran awal bahwa inovasi memiliki sifat dan ruang lingkup yang sangat fleksibel. Fleksibilitas sifat inovasi tersebut, salah satunya, dapat ditinjau dari sumber munculnya inovasi itu sendiri. 
Inovasi tak harus rigid diarahkan atau dilegitimasi oleh otoritas dengan hierarki yang lebih tinggi melalui berbagai kebijakan inovasi secara top-down, namun dapat pula berasal dan tumbuh dari masyarakat akar rumput dengan model bottom-up (Blake \& Garzon, 2012; Dana et al., 2019; Halvorsen et al., 2015; Hilmi, 2012; Hossain, 2016; Hua et al., 2010; Pansera, 2013; Seyfang \& Smith, 2007; Smith \& Stirling, 2016). Inovasi dengan model bottom-up seperti ini diyakini lebih berkelanjutan dalam mengatasi masalah lokal di tingkat masyarakat (Boyer, 2014; Dana et al., 2019; Ely, Smith et al., 2013; Hossain, 2016).

\section{B. Inovasi Menggunaakan Pendekatan Akar Rumput}

Pendekatan akar rumput menghasilkan solusi bottom-up yang menanggapi konteks, minat, dan nilai-nilai masyarakat yang terlibat secara aktif (A. K. Gupta et al., 2003; Hossain, 2016; Seyfang \& Smith, 2007). Sebagai produk atau proses inovatif yang dibuat pada bagian bawah piramida, inovasi akar rumput biasanya tumbuh karena kebutuhan, kesulitan dan tantangan yang dihadapi oleh suatu komunitas (Hilmi, 2012; Hua et al., 2010; Pansera, 2013) untuk menciptakan solusi sederhana dari masalah atau kesulitan hidup tersebut (Ely et al., 2013; Anil K. Gupta, 2016; S. Gupta, 2019; Reinsberger et al., 2015; Seyfang \& Haxeltine, 2012) dan memberikan jawaban terhadap ketidakadilan sosial (Smith et al., 2016) yang tidak dapat dijangkau oleh inovasi konvensional (Dana et al., 2019; Hossain, 2016; Smith, 2016).

Dalam konteks Indonesia, kondisi komunitas atau masyarakat dengan karakteristik seperti itu banyak dijumpai pada tingkat pedesaan. Data BPS-RI (2019) menginformasikan bahwa jumlah masyarakat miskin di pedesaan masih jauh lebih banyak daripada masyarakat miskin di perkotaan, yakni sebanyak 9,99 juta jiwa masyarakat miskin di perkotaan dan 15,15 juta jiwa masyarakat miskin di pedesaan. Kondisi ini menggambarkan bahwa masyarakat pada bagian bawah piramida (bottom of the pyramid) di Indonesia lebih banyak terdapat di pedesaan. Hal ini mendukung pandangan (Zhang, 
2012) bahwa konsep inovasi akar rumput memang lebih cocok disematkan pada inovasi yang dilakukan oleh masyarakat maupun komunitas pedesaan, termasuk di Indonesia.

Sebagai komunitas formal warga yang terkecil, atau menurut Undang-Undang Nomor 6 Tahun 2014 tentang Desa disebut sebagai kesatuan masyarakat hukum yang memiliki otonomi, Desa di Indonesia sebenarnya sudah berkembang sangat pesat. Hal tersebut tidak terlepas dari kebijakan, program, dan inovasi pembangunan desa yang telah dilakukan oleh pemerintah untuk menyelesaikan masalah kemiskinan. Kebijakan dan berbagai inovasi tersebut diantaranya adalah memprioritaskan pembangunan dari daerah pinggiran sebagaimana tercantum dalam Nawacita ke-3 (periode pemerintahan pertama Presiden Joko Widodo), gelontoran dana desa, program padat karya tunai, pengembangan Produk Unggulan Kawasan Perdesaan (Prukades), membangun embung air desa, mengembangkan Badan Usaha Milik Desa (BUMDes), dan beberapa inovasi lainnya.

Pemberian dana desa yang juga diiringi dengan berbagai inovasi pembangunan desa yang bersifat top-down ternyata belum efektif dan tidak dapat serta merta memberikan 'daya lenting' terhadap kesejahteraan masyarakat desa (Amalia et al., 2018; Aziz, 2016; Kambey, 2017; Meutia \& Liliana, 2017; Sulastri, 2016). Hal tersebut diakibatkan karena program yang tidak tepat sasaran, rumitnya birokrasi dan sistem pertanggungjawaban, ketidaksiapan aparatur pemerintah desa, peraturan yang tumpang tindih, hingga permasalahan korupsi. Kebijakan dan inovasi yang dilakukan pemerintah secara topdown tersebut akhirnya tidak efektif dalam menyelesaikan permasalahan masyarakat lokal di tingkat desa.

Tidak efektifnya kebijakan dan inovasi yang bersifat topdown tersebut sejalan dengan pandangan Smith (2016) bahwa inovasi konvensional sebenarnya tidak cocok dan tidak dapat memenuhi aspirasi lingkungan, sosial dan ekonomi dari masyarakat pada berbagai komunitas. Pada poin ini, desa akhirnya berinovasi secara mandiri, oleh dan untuk masyarakat 
akar rumput itu sendiri (S. Gupta, 2019) sebagai suatu komunitas secara bottom-up untuk menyelesaikan masalah yang mereka hadapi, salah satunya dengan berinovasi melalui transformasi desa menjadi desa wisata, termasuk apa yang dilakukan oleh Desa Wisata Pentingsari.

\section{Inovasi Pada Desa Wisata Pentingsari}

Desa Wisata Pentingsari atau yang lebih dikenal dengan sebutan 'Dewi Peri' merupakan salah satu desa wisata yang secara administratif berada pada wilayah Desa Umbulharjo, Kecamatan Cangkringan, Kabupaten Sleman, Provinsi Daerah Istimewa Yogyakarta (DIY). Dewi Peri pada tahun 1990-an merupakan salah satu desa miskin di wilayah DIY, bahkan jika dibandingkan dengan desa atau dusun lain di sekitarnya. Masyarakat disana pada awalnya memiliki pendapatan dan kemampuan ekonomi yang relatif rendah dengan kehidupan warganya yang sangat sederhana. Kondisi minus desa tersebut setidaknya bertahan hingga belasan tahun sampai pada akhirnya terdapat mufakat warga Dewi Peri untuk memulai perubahan, berinovasi dan menerima lingkungan luar sebagai salah satu Desa Wisata di Kabupaten Sleman, Provinsi DIY.

Dewi Peri kemudian secara legal berubah status menjadi salah satu desa wisata pada tanggal 15 April 2008, setelah sebelumnya mengajukan proposal kepada Dinas Pariwisata Kabupaten Sleman pada Bulan Maret 2008 dan dilakukan survey oleh Pemerintah Kabupaten Sleman pada tanggal 1 April 2008. Setelah sah menjadi salah satu desa wisata, Dewi Peri terus berbenah dan berinovasi untuk memajukan sektor pariwisata di wilayahnya. Berbagai hal inovatif yang mendukung kesuksesan Dewi Peri sebagai desa wisata terus dilakukan dan dikembangkan, bahkan hingga saat ini.

Inovasi yang dilakukan di Dewi Peri ternyata berbanding lurus dengan peningkatan pendapatan dan kemampuan ekonomi warga disana (Dinas Pariwisata Provinsi DIY, 2014; Suarthana, 2015; Tyas \& Asnawi, 2014). Warga Dewi Peri kelimpahan berkah ekonomi yang luar biasa akibat sumber 
penghasilan yang semakin banyak tersedia, mulai dari biaya homestay atau penginapan, menjadi tour guide atau pemandu wisata, dan biaya jasa lainnya yang juga merupakan fasilitas wisata berbasis keunikan sumber daya alam yang ditawarkan dalam banyak paket wisata di Dewi Peri tersebut.

Apabila mengacu pada pernyataan Schumpeter (1934) yang dikenal sebagai Prophet of Innovation atau 'Nabi'nya inovasi (Croitoru, 2017), ia memberikan definisi bahwa inovasi merupakan kombinasi baru dari produk, proses kerja, pasar, maupun organisasi baru. Jika ditarik pada kasus di Dewi Peri, maka apa yang terjadi disana tentunya merupakan sebuah inovasi produk. Produk inovasi itu sendiri merupakan produk jasa (Hazel Kaya, 2015; Helmi, 2016) yang ditawarkan oleh Dewi Peri dalam berbagai bentuk jasa wisata.

Dewi Peri berhasil memunculkan produk inovasi dalam bentuk desa wisata yang dikemas dalam branding nama 'Dewi Peri' (sebuah sebutan nama yang sangat menarik perhatian calon wisatawan) yang menawarkan jasa wisata berbasis pedesaan sebagai unsur utama dari produk inovasi itu sendiri. Hasilnya, berbagai bentuk jasa wisata yang ditawarkan disana, mulai dari memancing, membajak sawah, panen padi, susur sungai, wisata kebun durian, belajar karawitan, gamelan, menari tradisional hingga membuat kreasi dari produk janur nyatanya telah memberikan manfaat ekonomi luar biasa bagi masyarakat Dewi Peri.

Pendapatan warga Dewi Peri melonjak naik secara signifikan jika dibandingkan sebelum Dewi Peri berinovasi menjadi desa wisata dan masih menjadi salah satu desa miskin di wilayah DIY kala itu. Pada tahun 2017, omset warga Dewi Peri dari pengelolaan pariwisatanya mencapai Rp 2,5 Milyar per tahunnya, melonjak dari hanya sebesar Rp 30 Juta dalam setahun pada tahun 2008. Hal ini juga diakibatkan dari tumbuhnya homestay disana, dari hanya sebanyak 10 buah sejak tahun 2008 hingga terdapat 50 buah pada tahun 2017 serta jumlah wisatawan yang datang mencapai sekitar 35 ribu wisatawan dalam setahun. Atas keberhasilan ini, Dewi Peri 
akhirnya juga mampu mendapatkan berbagai penghargaan prestisius pada tingkat nasional maupun internasional.

Perubahan yang dilakukan oleh warga Dewi Peri dan kemudian dirasakan keberhasilan dan manfaatnya oleh warga desa disana tentu merupakan sebuah inovasi akar rumput yang secara nyata berhasil dilakukan, yakni inovasi yang muncul dari warga Desa Pentingsari yang sebelumnya hidup dalam kemiskinan dan keterisolasian (Anil K. Gupta, 2016; Hilmi, 2012; Reinsberger et al., 2015) hingga mampu menghadirkan kesejahteraan masyarakat melalui produk wisata yang mengedepankan kesederhanaan, kehidupan alami pedesaan, serta keberlanjutan lingkungan (Abrol \& Gupta, 2014; Boyer, 2014; S. Gupta, 2019; Hossain, 2016; Pansera, 2013; Seyfang \& Smith, 2007; White \& Stirling, 2013). Hal ini tentu menjadi objek penelitian menarik untuk melihat bagaimana inovasi akar rumput di Dewi Peri dilakukan beserta faktor pendorong dan penghambatnya, sehingga kemudian menghasilkan berbagai produk inovasi yang sukses meraih banyak penghargaan dan membawa masyarakatnya memiliki kehidupan ekonomi lebih baik.

Keberhasilan inovasi akar rumput yang dilakukan di Dewi Peri memunculkan pertanyaan penting lainnya, yakni terkait aktor (siapa) yang menjadi penggerak dari gerakan inovasi tersebut. Ada inovasi tentu ada inovator yang menjadi aktor penggerak. Beberapa akademisi memiliki pandangan variatif yang saling memperkuat ketika berbicara tentang aktor penggerak inovasi akar rumput. Hilmi (2012) menyebutkan bahwa inovasi akar rumput dilakukan oleh kelompok masyarakat pada bagian bawah piramida (bottom of the pyramid), sedangkan Anil K. Gupta (2016) menyebutnya dengan orang-orang biasa. Hal tersebut diperkuat oleh Seyfang \& Smith (2007) dan Hossain (2016) yang menyebutkan bahwa inovasi akar rumput dilakukan oleh kelompok masyarakat dan aktivis yang bekerjasama, dan bukan berasal dari lembaga inovasi maupun otoritas pembuat kebijakan (Hua et al., 2010; Reinsberger et al., 2015; Smith \& Stirling, 2016). 


\section{Kepemimpinan Akar Rumput}

Pandangan beberapa tokoh tersebut menjelaskan tentang profil dan latar belakang aktor yang menjadi penggerak dan pelaku inovasi akar rumput. Namun hal tersebut belum mampu menjelaskan tentang 'bagaimana' peran dari tokoh penggerak tersebut dalam memunculkan suatu inovasi dari masyarakat 'bawah'. Untuk mendapatkan analisis yang lebih mendalam terkait peran dari aktor penggerak tersebut, pendekatan konsep kepemimpinan (leadership), terutama tentang kepemimpinan akar rumput menjadi penting untuk dilakukan. Hal ini juga sesuai dengan pandangan Croitoru (2017) yang menyebutkan bahwa inovasi selalu dikaitkan dengan munculnya kepemimpinan yang baru.

Kepemimpinan akar rumput meletakan partisipasi, demokrasi dan pemberdayaan masyarakat untuk sebuah proyek perubahan sosial dalam organisasi nirlaba/kelompok masyarakat (Boehm \& Staples, 2005). Kepemimpinan model ini mengedepankan proses co-kreatif, dinamis, transformasional, responsif, stratejik, dan berorientasi perubahan (Wynne, 2012). Kedua pandangan tersebut menjelaskan bahwa perubahan masih menjadi kata kunci dalam konsep kepemimpinan apapun, termasuk kepemimpinan akar rumput.

Kepemimpinan akar rumput tetaplah berbeda dengan konsep kepemimpinan secara umum (Kellogg, n.d.). Perbedaan antara konsep kepemimpinan secara umum dan kepemimpinan akar rumput ialah bahwa pemimpin akar rumput lahir dari situasi dan kondisi yang lebih menantang, berasal dari 'bawah' (Wynne, 2012), hingga pada satu titik pemimpin ini akan membuat pergerakan bersama komunitasnya untuk menuju satu tujuan tertentu (Kellogg, n.d.), Hal tersebut disepakati oleh Borregard (2016) yang menyebutkan bahwa pemimpin top-down terkadang tidak cocok dalam suatu komunitas dan kepemimpinan bottom-up tanpa posisi formal dapat memainkan peran yang lebih penting.

Pendapat dari beberapa tokoh tentang kepemimpinan akar rumput tersebut tampak memiliki irisan besar dengan 
konsep inovasi akar rumput itu sendiri. Hal tersebut dapat dilihat dari orientasi perubahan yang dibawa, model bottom-up yang serupa diantara keduanya, profil atau latar belakang pemimpin dan aktor penggerak inovasi akar rumput, serta tujuan atau maksud dari inovasi dan kepemimpinan akar rumput. Oleh karena itu, tulisan ini sepakat bahwa perubahan yang dimunculkan oleh aktor penggerak inovasi akar rumput membuat aktor tersebut layak pula disebut sebagai pemimpin akar rumput (grassroot leader).

Penjelasan tentang kepemimpinan akar rumput pada inovasi akar rumput yang terjadi di Dewi Peri tentu akan berhadapan dengan beberapa diskursus menarik. Hal itu dapat dilihat dari distribusi kesejahteraan kepada warga desa atas pemanfaatan barang publik ataupun barang privat dalam paket wisata yang ditawarkan, interaksi antar aktor, hingga sampai pada kemungkinan adanya fenomena elite capture. Oleh karena itu, pembahasan tentang peranan kepemimpinan akar rumput pada inovasi akar rumput yang terjadi di Dewi Peri memang merupakan bagian topik penting untuk dilihat dalam penelitian ini dengan dukungan penjelasan dari beberapa hal yang menjadi kemungkinan diskursus tersebut (distribusi kesejahteraan atas barang publik atau privat dalam paket wisata, interaksi antar aktor, dan fenomena elite capture).

Berdasarkan penjelasan tersebut, keberhasilan inovasi akar rumput yang dilakukan di Dewi Peri pasca perubahan status desa menjadi desa wisata sejak tahun 2008 yang ditunjukkan dengan capaian berbagai penghargaan prestisius dan peningkatan pendapatan masyarakatnya tentu sangat menarik untuk diteliti secara ilmiah. Selain ketertarikan untuk meneliti lebih mendalam tentang bagaimana proses inovasi dilakukan untuk memunculkan sebuah produk inovasi akar rumput beserta faktor pendorong dan penghambatnya, penelitian juga menarik untuk dilanjutkan dengan melihat bagaimana peran aktor inovasi akar rumput dalam proses tersebut melalui pendekatan konsep kepemimpinan akar rumput. 


\section{BAB II \\ INOVASI AKAR RUMPUT}

\section{A. Pengertian Inovasi}

Inovasi berasal dari kata "innavatus" dalam bahasa Latin yang berarti membuat sesuatu yang baru (Hazel Kaya, 2015). Beberapa definisi awal tentang inovasi kemudian terus berkembang. Meskipun poin besar mereka tetap merujuk pada ide kebaruan. Beberapa tokoh klasik studi inovasi memberikan definisi inovasi yang dirangkum dalam tulisan Godin (2008), memberikan definisi inovasi sebagai berikut:

1. Hart (1931): making new working adjustments (combination) among material and socio-psychological culture;

2. Ogburn (1941): inventions that have served to transform the environment profoundly;

3. Rogers (1962): an idea, procedure or object perceived as new by its adopter.

Dari ke-tiga tokoh tersebut, dapat dilihat diskursus pandangan setiap tokoh dalam memberikan definisi tentang inovasi. Namun setidaknya definisi dari ke-tiga tokoh klasik tersebut dapat memberikan gambaran tentang apa sebenarnya inovasi itu. yang jika diintisarikan menurut pandangan tokohtokoh tersebut, bahwa unsur utama dari inovasi itu adalah "kebaruan". Hal ini tentu sejalan dengan pandangan Schumpeter (1934) yang dikenal sebagai Prophet of Innovation atau 'Nabi'nya inovasi (Croitoru, 2017), ia memberikan definisi bahwa inovasi merupakan kombinasi baru dari produk, proses kerja, pasar, maupun organisasi baru.

Meskipun sejak akhir 1880-an telah ada laporan penggunaan istilah "inovasi" untuk mengartikan sesuatu yang tidak biasa, Schumpeter adalah orang pertama dan yang paling berpengaruh dalam menjelaskan secara jelas tentang konsep inovasi (Lazzarotti et al., 2011; Śledzik, 2013). Karya Schumpeter (1934) ini terus dikutip oleh banyak peneliti dan 
akademisi bahkan hingga lebih dari 10.000 kali setiap tahunnya (Croitoru, 2017). Sekali lagi, sesuai simpulan awal tadi, kebaruan merupakan unsur pembangun utama dari sebuah inovasi.

Sementara itu, perlu juga bagi kita untuk melihat definisi tentang inovasi dari beberapa tokoh dalam kurun waktu yang lebih 'muda'. Hana (2013) misalnya, menerangkan bahwa inovasi adalah sumber utama keunggulan kompetitif yang menentukan keberhasilan ekonomi organisasi. Pendapat Hana (2013) ini didukung oleh Shqipe, et al (2013) yang berpandangan bahwa jika organisasi ingin bertahan dan tumbuh di lingkungan yang sangat kompetitif seperti saat ini, mereka harus melakukan segala upaya melalui strategi yang inovatif. Pandangan dari Hana (2013) dan Shqipe, et al (2013) ini setidaknya memberikan pengayaan kepada kita dalam menggali definisi atau makna inovasi pada abad ke-21 saat ini dan melengkapi pandangan beberapa tokoh klasik terhadap definisi inovasi yang mereka kemukakan pada pertengahan abad ke-20 saat itu (Hart, Ogburn, dan Rogers dalam Godin, 2008; Schumpeter, 1934).

Berdasarkan pandangan tentang definisi yang dikemukakan para tokoh tersebut, meskipun konsep inovasi ini masih terus berkembang dan belum matang (Zuhal, 2013), diperoleh intisari bahwa inovasi merupakan suatu hal baru, baik itu produk, proses, objek, pasar, organisasi, atau budaya yang memberikan kemanfaatan terhadap eksistensi dan keunggulan kompetitif suatu komunitas atau organisasi untuk dapat 'bertahan hidup' di era penuh persaingan dan ketidakpastian. Definisi ini tentu tidak memiliki eksklusi pada siapa yang melakukan inovasi tersebut, baik secara top-down melalui lembaga formal, otoritas pemerintahan dan organisasi profit maupun secara bottom-up melalui komunitas, LSM, ataupun masyarakat pada tingkat akar rumput sekalipun (Blake \& Garzon, 2012; Dana et al., 2019; Halvorsen et al., 2015; Hilmi, 2012; Hossain, 2016; Hua et al., 2010; Pansera, 2013; Seyfang \& Smith, 2007; Smith \& Stirling, 2016). 
Mendengar lembaga formal, otoritas pemerintahan ataupun organisasi profit melakukan inovasi tentu merupakan hal biasa karena dorongan kompetisi (Hana, 2013; Shqipe et al., 2013). Organisasi publik (pemerintahan) akan berinovasi dalam mengembangkan layanan publik untuk memenuhi kebutuhan publik yang semakin kompleks (Koch \& Hauknes, 2005). Sedangkan organisasi profit akan melakukan inovasi untuk mempertahankan eksistensi perusahaan mereka, menembus pasar yang lebih luas, dan tentunya keuntungan yang lebih besar (Shqipe et al., 2013). Namun inovasi dengan model topdown konvensional tersebut ternyata gagal menyentuh dan memberikan solusi terhadap masalah komunitas pada tingkat lokal (Dana et al., 2019; Hossain, 2016; Smith, 2016), sehingga inovasi konvensional perlu mengembangkan metode baru yang lebih sesuai dengan kondisi lokal (Ahmed \& Al-Roubaie, 2012). Inovasi akar rumput akhirnya tumbuh sebagai jawaban atas gap tersebut dan kemudian melengkapinya (Ornetzeder \& Rohracher, 2013).

Sebelum lanjut pada konsep beserta kajian literatur selanjutnya, perlu digaris bawahi bahwa 'inovasi proses' sebagaimana yang disebutkan oleh Schumpeter (1934) sebagai salah satu bentuk inovasi pada dasarnya berbeda dengan 'proses inovasi' yang diteliti pada penelitian ini. Apa yang terjadi di Dewi Peri merupakan sebuah hasil inovasi yang dikemas dalam produk jasa (Hazel Kaya, 2015; Helmi, 2016). Produk inovasi ini diberikan branding nama 'Dewi Peri' (nama yang sangat unik untuk menarik calon wisatawan) yang menawarkan jasa wisata berbasis pedesaan sebagai unsur utama dari produk inovasi itu sendiri.

'Desa Wisata' faktanya merupakan hal baru bagi Dewi Peri. Sehingga, letak inovasi di Dewi Peri itu sendiri berada pada produk yang dihasilkan, bukan pada prosesnya. Namun penelitian ini telah memilih fokus untuk melihat bagaimana sebetulnya proses yang terjadi di Dewi Peri dalam memunculkan produk inovasi itu sendiri, dalam hal ini tentunya adalah inovasi akar rumput. Hal ini sesuai dengan 
pandangan Hazel Kaya (2015) yang menyebut bahwa 'proses inovasi' akan terus mengiringi sebuah (produk) inovasi yang dilakukan. Penelitian ini pun demikian, fokus untuk melihat pada proses yang dilakukan dalam memunculkan sebuah produk inovasi akar rumput di Dewi Peri. Secara sederhana, penjelasan tersebut dapat dilihat dari skema berikut ini.

Gambar 2.1

Posisi Fokus Inovasi pada Penelitian Ini

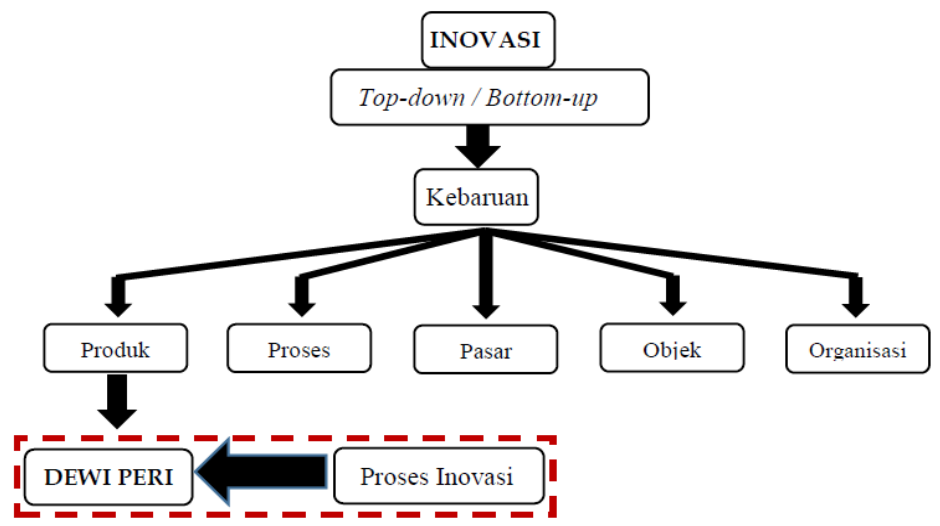

Sumber: Diolah penulis dari berbagai dokumen (2020).

\section{B. Inovasi Akar Rumput}

Meskipun sudah sampai 2 (dua) dekade penelitian, tidak ada tinjauan yang sistematis dari literatur inovasi akar rumput (Hossain, 2016). Hal tersebut membuat Hossain (2016) menyusun artikel dengan judul "Grassroots Innovation: A Systemic of Two Decades of Research" yang bertujuan untuk mensintesis literatur inovasi akar rumput. Tulisan tersebut menyebutkan bahwa literatur-literatur inovasi akar rumput yang muncul sejak dua dekade lalu masih belum tersusun sistematis walaupun inovasi akar rumput itu sendiri telah menjadi disiplin ilmu yang mapan. Namun di sisi lain, Hossain (2016) mengakui bahwa definisi inovasi akar rumput yang paling sering dirujuk oleh penulis dan akademisi ialah definisi dari Seyfang \& Smith (2007). 
Seyfang \& Smith (2007) berpandangan bahwa inovasi akar rumput adalah serangkaian kegiatan kelompok masyarakat dan aktivis yang bekerjasama dengan orang-orang untuk menghasilkan produk atau solusi dari bawah ke atas untuk pembangunan berkelanjutan. Solusi tersebut menanggapi situasi lokal, minat, dan nilai-nilai masyarakat. Masyarakat tersebut terlibat aktif dan memiliki kendali atas proses dan hasil. Sedangkan pada literatur-literatur lainnya, Hilmi (2012) mendefinisikan inovasi akar rumput sebagai produk atau proses inovatif yang dibuat di bagian bawah piramida, biasanya karena kebutuhan, kesulitan dan tantangan (Hilmi, 2012; Hua et al., 2010; Pansera, 2013). Hal ini disepakati oleh beberapa tokoh (Ely, 2013; A. K. Gupta, 2016; S. Gupta, 2019; Reinsberger et al, 2015; Seyfang \& Haxeltine, 2012) yang menyatakan bahwa inovasi berasal dari orang-orang biasa yang mampu menciptakan solusi sederhana dari masalah atau kesulitan hidup mereka.

Lebih jauh, Smith, et al (2016) menyebutkan bahwa inovasi akar rumput tumbuh dari dorongan untuk memberikan jawaban terhadap ketidakadilan sosial yang dipaksakan oleh sistem teknologi yang ada. Pada tulisan lainnya, Smith \& Stirling (2016) menyebutkan bahwa inovasi akar rumput tidak secara formal dilakukan oleh lembaga inovasi maupun otoritas pembuat kebijakan inovasi. Zhang (2012) bahkan secara lebih spesifik menyebutkan bahwa inovasi akar rumput biasanya dilakukan oleh masyarakat atau komunitas di pedesaan. Pandangan beberapa tokoh tersebut setidaknya telah memberikan jawaban singkat kepada kita tentang siapa dan mengapa inovasi akar rumput dilakukan. Penulis mencoba menggambarkannya seperti pada tabel berikut ini. 